Zeszyty Naukowe Szkoły Głównej Gospodarstwa Wiejskiego

Ekonomika i Organizacja Gospodarki Żywnościowej nr 116, 2016: 95-104

Kinga Gruziel

Katedra Ekonomii i Polityki Gospodarczej

Szkoła Główna Gospodarstwa Wiejskiego w Warszawie

\title{
Zasady prowadzenia i opodatkowania sprzedaży bezpośredniej przetworzonych produktów rolnych w Polsce
}

\section{Wstęp}

Wraz z wstapieniem Polski w struktury Unii Europejskiej (UE) 1 maja 2004 roku pojawiły się możliwości przejęcia sprawdzonych wzorców systemu certyfikowania, znakowania i sprzedaży produktów pochodzenia rolniczego. Korzystając z wzorców europejskich, rolnicy w Polsce dostrzegli możliwości pozyskiwania alternatywnych źródeł utrzymania z działalności rolniczej. Rozstrzygnięcia Parlamentu Europejskiego w sprawie systemów jakości produktów rolnych i środków spożywczych wprowadziły istotne zmiany w obrębie identyfikowania, rejestrowania obrotu produktami rolnymi o charakterze „tradycyjnym” [Rozporządzenie Parlamentu Europejskiego i Rady UE 1151/2012]. Przyjęte rozstrzygnięcia wzmocniły system kontroli i nadzoru państwa nad prawidłowym funkcjonowaniem obrotu produktami pochodzenia rolniczego. Zadania państw członkowskich wpisano expresis verbis do tekstu rozporządzenia w celu zapewnienia większej pewności prawa. Przedmiotowe zadania państw członkowskich obowiązują na podstawie innych przepisów i są wdrożone także do polskiego porząaku prawnego.

Sprzedaż bezpośrednia, według definicji Światowej Federacji Sprzedaży Bezpośredniej (the World Federation of Direct Selling Association - WFDSA), jest określana jako szybko rozwijający i dynamiczny kanał dystrybucji produktów i usług bezpośrednio do klienta ${ }^{1}$. Sprzedaż bezpośrednia to kanał detaliczny stosowany zarówno przez podmioty reprezentujące najlepsze światowe marki, jak i mniejsze firmy prowadzące działalność na rynku produktów i usług konsumpcyjnych. Ta forma kontaktów między sprzedawcą a nabywcą dotyczy

\footnotetext{
${ }^{1}$ http://wfdsa.org/about-d.i.rect-selling/ [dostęp: 16.12.2016].
} 
różnorodnych towarów i usług, począwszy od żywności, kosmetyków, sprzętu AGD, energii, ubezpieczeń itp.

Polskie Stowarzyszenie Sprzedaży Bezpośredniej (PSSB) podaje definicję tej formy sprzedaży jako oferowanie towarów i usług bezpośrednio konsumentom na zasadach kontaktów indywidualnych, zazwyczaj w domu klienta, miejscu pracy lub w innych miejscach, poza stałymi punktami sprzedaży detalicznej. Sprzedaż bezpośrednia jest formą sprzedaży detalicznej prowadzonej poza siecią sklepową i wymagającą osobistej prezentacji produktu i udzielenia stosownych wyjaśnień.

Obowiązująca w Polsce definicja sprzedaży bezpośredniej wynika z zapisów prawnych i jest skonstruowana z poszanowaniem rozstrzygnięć wspólnotowych odnośnie zasad i wymagań prawa żywnościowego [Rozporządzenie (WE) 178/2002]. W projekcie ustawy o sprzedaży żywności przez rolników oraz zmianie niektórych innych ustaw (art. 2) stwierdzono, że sprzedaż żywności przez rolników jest końcowym etapem procesu produkcji i przetwarzania przez rolnika żywności i przysługuje z tytułu prowadzenia gospodarstwa rolnego. W artykule 3 doprecyzowano istotę sprzedaży żywności przez rolników, rozumianej jako sprzedaż przetworzonych i nieprzetworzonych produktów żywnościowych pochodzących bezpośrednio z własnej uprawy, chowu lub hodowli pszczelarskiej i pasterstwa, dokonywanych przez rolnika, jego najbliższą rodzinę lub osoby zamieszkujące na stałe w gospodarstwie rolnym. Celem wprowadzonych i omawianych rozwiązań ustawowych było stworzenie warunków do sprzedaży produktów wytwarzanych bezpośrednio przez rolników z wykorzystaniem własnych, tradycyjnych, ale również sprawdzonych przepisów i metod produkcji.

Obowiązującymi zapisami prawnymi określającymi zasady rolniczego handlu detalicznego ustawodawca określa produkcję i sprzedaż żywności w ilościach dostosowanych do potrzeb konsumenta, która nie stanowi zagrożenia dla bezpieczeństwa żywności i nie ma negatywnego wpływu na zdrowie publiczne. Jednocześnie realizowane produkcja i sprzedaż podlegają nadzorowi organów Państwowej Inspekcji Sanitarnej lub Inspekcji Weterynaryjnej oraz udokumentowaniu, co umożliwia określenie ilości zbywanej żywności np. podczas wystaw, festynów, targów czy kiermaszów z zastrzeżeniem prowadzenia sprzedaży z wyłączeniem pośredników oraz określenia miejsca sprzedaży do obszaru obowiązującego lub sąsiedniego powiatu dla miejsca produkcji [Ustawa z dnia 16 listopada 2016 r.].

\section{Cel i metodyka badań}

Celem opracowania jest próba zidentyfikowania najważniejszych zagadnień związanych z prowadzeniem przez rolników sprzedaży bezpośredniej przetworzonych produktów rolnych. Podjęto próbę przedstawienia zasad prowadzenia 
sprzedaży bezpośredniej oraz rozstrzygnięć podatkowych będących skutkiem realizowania tego typu działalności. Na podstawie obowiązujących aktów prawnych omówiono samą definicję sprzedaży bezpośredniej, warunki jej realizowania oraz zasady powstawania i realizacji obowiązku podatkowego.

W opracowaniu dokonano analizy konstrukcji i rozwiązań podatkowych dotyczących sprzedaży bezpośredniej. Wykorzystano metody obserwacji, analizy i rozbioru logicznego zasad opodatkowania sprzedaży bezpośredniej. Podstawę stanowiły badania jakościowe, z których najistotniejsze były analiza dokumentów oraz metody dedukcji i wnioskowania.

\section{Wyniki badań}

$\mathrm{Z}$ dniem 1 stycznia 2016 roku na mocy ustawy z 9 kwietnia 2015 roku zaczęły obowiązywać przepisy regulujące zasady sprzedaży bezpośredniej przetworzonych produktów rolnych. Nowe regulacje wprowadzono ustawą o zmianie ustawy o podatku dochodowym od osób fizycznych oraz niektórych innych ustaw, które to zapisy regulują zasady sprzedaży bezpośredniej przetworzonych produktów rolnych. Obowiązujący stan prawny dyktują nowoprzyjęte przepisy krajowe:

- ustawa z 9 kwietnia 2015 roku o zmianie ustawy o podatku dochodowym od osób fizycznych oraz niektórych innych ustaw, która pozwala na identyfikowanie przychodów uzyskiwanych przez rolników ze sprzedaży produktów przetworzonych w sposób inny niż przemysłowy, a pochodzących z własnych upraw;

- rozporządzenie Ministra Rolnictwa i Rozwoju Wsi z 30 września 2015 roku w sprawie wymagań weterynaryjnych przy produkcji produktów pochodzenia zwierzęcego przeznaczonych do sprzedaży bezpośredniej, w którym określono wymagania weterynaryjne, jakie powinny być spełnione przy produkcji przeznaczonej do sprzedaży, między innymi: jej wielkość, zakres, obszar oraz wymagania weterynaryjne dla miejsc prowadzenia sprzedaży bezpośredniej;

- $\quad$ wytyczne Dobrej praktyki higienicznej i produkcyjnej, określające prowadzenie produkcji w warunkach domowych, środków spożywczych pochodzenia niezwierzęcego, z wykorzystaniem surowców roślinnych pochodzących z własnych upraw (pola, ogrodu);

- rozporządzenie Ministra Rolnictwa i Rozwoju Wsi z 21 marca 2016 roku w sprawie szczegółowych warunków uznania działalności marginalnej, lokalnej i ograniczonej, omawiające szczegółowe warunki uznania działalności za marginalną, lokalną i ograniczoną, określające wymagania weteryna- 
ryjne, jakie powinny być spełnione przy prowadzeniu tych działalności, ich zakres, obszar produkcji i wielkość dostaw produktów pochodzenia zwierzęcego do zakładów prowadzących handel detaliczny z przeznaczeniem dla konsumenta końcowego;

- rozporządzenie Ministra Zdrowia z 6 czerwca 2007 roku w sprawie dostaw bezpośrednich środków spożywczych, określające zakres i wymagania higieniczne dla działalności prowadzonej w ramach dostaw bezpośrednich realizowanych przez producentów rolnych do konsumentów finalnych;

- ustawa z 16 listopada 2016 roku o zmianie niektórych ustaw w celu ułatwienia sprzedaży żywności przez rolników, wprowadzającej zasady prowadzenia sprzedaży bezpośredniej i pojęcia rolniczego handlu detalicznego.

W projekcie ustawy o zmianie niektórych ustaw w celu ułatwienia sprzedaży żywności przez rolników stwierdzano konieczność wyeliminowania barier utrudniających rozwój produkcji i sprzedaży przez rolników żywności uzyskiwanej w całości lub części z własnych upraw, hodowli lub chowu, a skierowanych do konsumentów. Wątpliwości te odnoszono do działalności prowadzonej w ograniczonym rozmiarze i obejmującej krótkie łańcuchy sprzedaży (bezpośrednio od producenta do konsumenta, bez udziału pośredników). W polskich regulacjach brakowało wyraźnego określenia wymagań sanitarnych oraz stwierdzano wątpliwości dotyczące podziału kompetencji między Inspekcją Weterynaryjną a Państwową Inspekcją Sanitarną jako instytucjami określającymi zasady sprzedaży produktów pochodzenia rolniczego. Efektem był brak równych szans i możliwości w zakresie produkcji i przetwarzania żywności między polskimi rolnikami a rolnikami z innych państw członkowskich UE. Jako niedoskonałość rozwiązań prawnych podnoszono różne zasady opodatkowania sprzedaży produktów przetworzonych $\mathrm{z}$ własnej uprawy, hodowli lub chowu oraz brak jednoznacznego określenia, kiedy taka sprzedaż jest zwolniona z podatku dochodowego. Brak precyzyjnych zapisów powodował różnorodne interpretacje dokonywane przez urzędy skarbowe, niejednoznaczne ustalenia zdarzeń polegających opodatkowaniu i warunków zwolnienia z podatku dochodowego.

Na mocy ustawy z 9 kwietnia 2015 roku [Dz.U. 2015 r., poz. 699] wprowadzono ułatwienia dla rolników tytułem sprzedaży żywności z własnej uprawy, hodowli lub chowu. W zapisach ustawy dokonano doprecyzowania definicji przychodów uzyskiwanych tytułem prowadzenia sprzedaży bezpośredniej. Artykuł 20 pkt 1c ustawy o podatku dochodowym od osób fizycznych z 26 lipca 1991 roku precyzuje kategorie przychodów podlegających opodatkowaniu i wymienia pośród nich inne źródła przychodów, takie jak: przychody ze sprzedaży przetworzonych w sposób inny niż przemysłowy produktów roślinnych i zwierzęcych pochodzących z własnej uprawy, hodowli lub chowu, z wyjątkiem przetworzonych produktów roślinnych i zwierzęcych uzyskanych w ramach pro- 
wadzonych działów specjalnych produkcji rolnej oraz produktów opodatkowanych podatkiem akcyzowym na podstawie odrębnych przepisów, jeżeli:

- $\quad$ sprzedaż nie jest wykonywana na rzecz osób prawnych, jednostek organizacyjnych nieposiadających osobowości prawnej lub na rzecz osób fizycznych lub na potrzeby prowadzonej pozarolniczej działalności gospodarczej;

- przetwarzanie produktów roślinnych i zwierzęcych i ich sprzedaż nie jest realizowana przy zatrudnieniu osób na podstawie umów o pracę, umów zlecenia, umów o dzieło oraz innych umów o analogicznym charakterze;

- $\quad$ sprzedaż następuje wyłącznie w miejscach wytwarzania produktów oraz na targowiskach;

- prowadzona jest ewidencja sprzedaży;

- podatnik nie uzyskał innych przychodów tytułem pozarolniczej działalności gospodarczej.

Podatnicy osiagający przychody tytułem przetworzonych produktów roślinnych i zwierzęcych są obowiązani prowadzić ewidencję sprzedaży produktów odrębnie za każdy rok podatkowy. Informacjami identyfikującymi sprzedaż powinny być co najmniej: numer kolejnego wpisu, data uzyskania przychodu, kwota przychodu, przychód wyrażony narastająco od początku roku oraz ilość i rodzaj przetworzonych produktów. Dzienne przychody tytułem sprzedaży należy ewidencjonować w dniu sprzedaży. Samą ewidencję sprzedaży, jak stanowi zapis cytowanej ustawy w ust. 1e, należy posiadać w miejscu sprzedaży przetworzonych produktów roślinnych i zwierzęcych.

Zwolnienie przedmiotowe z podatku dochodowego od osób fizycznych obejmuje (zgodnie z art. 21 ust. 71) dochody ze sprzedaży produktów roślinnych i zwierzęcych pochodzących z własnej uprawy lub hodowli, niestanowiących działów specjalnych produkcji rolnej, przerobionych sposobem przemysłowym, jeżeli przerób polega na kiszeniu produktów roślinnych lub przetwórstwie mleka albo na uboju zwierząt rzeźnych i obróbce poubojowej tych zwierząt, w tym również na rozbiorze, podziale i klasyfikacji mięsa. Zwolnieniu podlegają przychody do kwoty 20 tys. PLN rocznie ze sprzedaży produktów nieprzekraczającej ilości, która może być zbywana w ramach handlu detalicznego. Uzyskany w roku podatkowym przychód powyżej limitów, o których mowa w ust. 1 pkt 71a, podatnik może opodatkować ryczałtem od przychodów ewidencjonowanych na zasadach określonych $w$ ustawie o zryczałtowanym podatku. Podatnicy opłacają $w$ roku podatkowym ryczałt od przychodów ewidencjonowanych $\mathrm{z}$ działalności wymienionej w ust. 1, jeżeli w roku poprzedzającym rok podatkowy uzyskali przychody z tej działalności, prowadzonej wyłącznie samodzielnie, w wysokości nieprzekraczającej 150 tys. EUR.

Kolejnym aktem prawnym regulującym zasady sprzedaży żywności przez rolników jest ustawa o zmianie niektórych ustaw w celu ułatwienia sprzedaży 
żywności przez rolników [Dz.U. 2016 r. z poz. 1961]. W art. 1 ustawodawca precyzuje pojęcie przychodów ze sprzedaży produktów przetworzonych w sposób inny niż przemysłowy, jeżeli ilość produktów roślinnych i zwierzęcych pochodzących z własnej uprawy, hodowli lub chowu, użytych do produkcji danego produktu, stanowi co najmniej 50\% tego produktu.

Warunkiem rozpoczęcia sprzedaży w ramach sprzedaży bezpośredniej przez rolnika jest:

- spełnienie określonych wymogów higieniczno-sanitarnych;

- uzyskanie zgody powiatowego lekarza weterynarii (w przypadku produktów pochodzenia zwierzęcego) lub państwowego powiatowego inspektora sanitarnego (w przypadku produktów pochodzenia niezwierzęcego i mieszanych).

Sprzedaż bezpośrednia nie może być dokonywana na rzecz osób prawnych, jednostek organizacyjnych nieposiadających osobowości prawnej lub na rzecz osób fizycznych na potrzeby prowadzonej przez nie pozarolniczej działalności gospodarczej. Sprzedaż nie może być prowadzona przy zatrudnieniu osób na podstawie umów o pracę, umów zlecenia, umów o dzieło oraz innych umów.

Rolnik w procesie wytwarzania i sprzedaży bezpośredniej produktów nieprzetworzonych, pochodzacych $\mathrm{z}$ własnego gospodarstwa, nie ma obowiązku rejestrowania działalności gospodarczej. Wpisu do rejestru przedsiębiorców wymaga wyrób i sprzedaż produktów przetworzonych, jeśli działalność jest wykonywana w celach zarobkowych w sposób zorganizowany i ciągły. Rejestracja działalności następuje poprzez złożenie formularza zgłoszenia w gminie, w której rolnik jest zameldowany.

Ustawodawca na mocy rozporządzenia Ministra Rolnictwa i Rozwoju Wsi z 30 września 2015 roku w sprawie wymagań weterynaryjnych przy produkcji produktów pochodzenia zwierzęcego przeznaczonych do sprzedaży bezpośredniej wprowadził limity wielkości sprzedaży bezpośredniej, wielkości produkcji produktów pochodzenia zwierzęcego przeznaczonych do sprzedaży bezpośredniej, które oszacowano na poziomie nie większym niż:

- 50 sztuk tygodniowo - w przypadku tusz indyków, wraz z podrobami pozyskanymi z tych indyków;

- 500 sztuk tygodniowo - w przypadku tusz gęsi, wraz z podrobami pozyskanymi z tych gęsi;

- 200 sztuk tygodniowo - w przypadku tusz innych gatunków drobiu niż wymienione powyżej, wraz z podrobami pozyskanymi z tego drobiu;

- 100 sztuk tygodniowo - w przypadku tusz zajęczaków, wraz z podrobami pozyskanymi z tych zajęczaków;

- 10 tys. kg rocznie - w przypadku tusz grubej zwierzyny łownej, wraz z podrobami pozyskanymi z tej zwierzyny; 
- 10 tys. kg rocznie - w przypadku tusz drobnej zwierzyny łownej, wraz z podrobami pozyskanymi z tej zwierzyny;

- $1000 \mathrm{~kg}$ rocznie - w przypadku żywych ślimaków lądowych;

- 10001 tygodniowo - w przypadku mleka surowego albo mleka surowego i siary;

- 2001 tygodniowo - w przypadku surowej śmietany;

- 2450 sztuk tygodniowo - w przypadku jaj pozyskanych od drobiu;

- 500 sztuk rocznie - w przypadku jaj pozyskanych od ptaków bezgrzebieniowych,

- ustawodawca nie ustalił limitów sprzedaży produktów pszczelich nieprzetworzonych i produktów pochodzących z rybołówstwa, ślimaków lądowych, tusz i tuszek zwierząt łownych, niemniej jednak produkty te powinny być sprzedawane jako produkty świeże.

Sprzedaż bezpośrednią można prowadzić na terenie województwa, w którym odbywa się produkcja lub na obszarze sąsiadujących z nim województw. W innych województwach (poza powyższymi) sprzedaż bezpośrednia jest możliwa podczas wystaw, festynów, targów lub kiermaszów, organizowanych w celu promocji tych produktów. Warunkiem koniecznym jest przekazanie powiatowemu lekarzowi weterynarii (właściwemu ze względu na miejsce sprzedaży), co najmniej na siedem dni przed dniem jej rozpoczęcia, pisemnej informacji zawierającej: imię i nazwisko/nazwę podmiotu oraz adres producenta, dane dotyczące miejsca i okresu, w których będzie prowadzona sprzedaż.

Przychody ze sprzedaży przetworzonych nie przemysłowo własnych produktów rolnych mogą być opodatkowane tylko w dwóch formach. Podstawową formą opodatkowania jest podatek dochodowy na zasadach ogólnych według skali podatkowej. W tej wersji podatnik-rolnik będzie mógł od uzyskanego przychodu z tytułu sprzedaży odjać koszty uzyskania tego przychodu, a następnie od tak uzyskanego dochodu wyliczyć podatek dochodowy według stawek 18 lub $32 \%$ (po przekroczeniu 85525 PLN dochodu). Podatek taki podlega wpłacie na konto urzędu skarbowego do 20. dnia następnego miesiąca, po miesiącu którego dotyczy. Dochody ze sprzedaży produktów rolnych będą łączyły się w zeznaniu rocznym PIT z innymi dochodami, np. z pracy, renty, emerytury itp.

Drugą formą opodatkowania jest ryczałt ewidencjonowany. Stawka ryczałtu ze sprzedaży wynosi $2 \%$ od całego przychodu bez pomniejszania o koszty uzyskania przychodu. Warunkiem rozliczenia ryczałtowego będzie prowadzenie ewidencji sprzedaży oraz sprzedawanie produktów wyłącznie w miejscu ich wytworzenia, czyli w gospodarstwie lub na targowiskach (wszelkie miejsca przeznaczone do prowadzenia handlu, z wyjątkiem sprzedaży dokonywanej w budynkach lub w ich częściach). Podatnik-rolnik ma obowiązek prowadzenia odrębnej ewidencji przychodów. Warunkiem zastosowania tej formy opodatko- 
wania jest złożenie przez rolnika zawiadomienia o wyborze ryczałtu ewidencjonowanego do właściwego ze względu na miejsce zamieszkania urzędu skarbowego. Pierwsze zawiadomienie po wejściu w życie zmian w przepisach należało złożyć do 20 stycznia 2016 roku. Rolnicy rozpoczynający taką sprzedaż w trakcie roku podatkowego powinni natomiast złożyć zawiadomienie przed uzyskaniem pierwszego przychodu z tego tytułu. Oświadczenie takie jest ważne na kolejne lata podatkowe i nie ma obowiązku składania go co roku. Jednakże w przypadku chęci rezygnacji z ryczałtu ewidencjonowanego należy dokonać tego do 20 stycznia roku podatkowego, od którego ma nastąpić zmiana na zasady ogólne. Niespełnienie warunków formalnych w zakresie prowadzenia ewidencji przychodów, zatrudnienia osób czy sprzedaży poza miejscami do tego przeznaczonymi może prowadzić do utraty ryczałtowej formy opodatkowania.

Wyłączone ze zwolnienia będą przychody ze sprzedaży przetworzonych produktów roślinnych i zwierzęcych uzyskane w ramach prowadzonych działów specjalnych produkcji rolnej oraz produktów opodatkowanych podatkiem akcyzowym (np. napoje alkoholowe). Zwolnienie nie znajdzie zastosowania, jeżeli sprzedaż będzie odbywała się na rzecz osób prawnych oraz jednostek organizacyjnych nieposiadających osobowości prawnej albo na rzecz osób fizycznych dla potrzeb prowadzonej przez nie pozarolniczej działalności gospodarczej.

Zwolnienie wyłączone będzie również wówczas, kiedy wytwarzanie przetworzonych produktów roślinnych i zwierzęcych i ich sprzedaż będą odbywały się przy udziale osób zatrudnionych na podstawie umów o pracę, umów zlecenia, umów o dzieło oraz innych umów o podobnym charakterze.

Ponadto ograniczona będzie liczba miejsc, w których możliwa będzie sprzedaż tych produktów, żeby skorzystać ze zwolnienia. Oprócz sprzedaży w miejscu, w którym produkty zostały wytworzone, dozwolona będzie sprzedaż przetworzonych produktów roślinnych i zwierzęcych na targowiskach.

Zwolnienie nie znajdzie zastosowania do podatników, którzy uzyskali inne przychody ze sprzedaży zaliczane do przychodów z pozarolniczej działalności gospodarczej.

Rolnicy mogą także wybrać formę zryczałtowanego zwrotu podatku VAT polegającą na uproszczonym rozliczaniu podatku VAT od sprzedaży produktów rolnych. Korzystają wówczas ze zwolnienia z obowiązku prowadzenia ewidencji sprzedaży, wystawiania faktur, składania deklaracji VAT, dokonania zgłoszenia rejestracyjnego.

Kwota ryczałtu jest wypłacana rolnikowi przez nabywcę produktów rolnych. Nabywca produktów rolnych - podatnik podatku VAT - wypłacony rolnikowi ryczałt podatkowy rozlicza z urzędem skarbowym.

Reasumując, w opracowaniu przedstawiono zagadnienie sprzedaży bezpośredniej jako działalności pozwalającej na pozyskiwanie przez rolników dodat- 
kowych źródeł dochodów. Przedstawione zasady prowadzenia sprzedaży bezpośredniej, wykorzystując wzorce europejskie, określają możliwości pozyskiwania alternatywnych źródeł utrzymania z działalności rolniczej.

Wprowadzenie do polskiego systemu prawnego konstrukcji sprzedaży bezpośredniej wydaje się być rozwiązaniem korzystnym nie tylko dla rolników prowadzących tego rodzaju działalność, ale również dla konsumentów. Rolnicy uzyskali perspektywy sprzedaży surowców i produktów po cenach rynkowych, a konsumenci mogą nabywać żywność w dobrej cenie $\mathrm{z}$ wiadomego źródła. Możliwość prowadzenia sprzedaży bezpośredniej jest korzystnym rozwiązaniem dla rolnika, gdyż pozyskanie zaufania klientów daje szanse sprzedaży produktów po cenach rynkowych, uzyskania stałych przychodów, a tym samym poczucie niezależności ekonomicznej.

\section{Podsumowanie}

W opracowaniu przedstawiono najważniejsze zagadnienia związane z prowadzeniem przez rolników sprzedaży bezpośredniej. Zaprezentowano definicje sprzedaży bezpośredniej wynikające zarówno z przepisów prawa polskiego, jak i unijnego. Przedstawiono główne zasady prowadzenia sprzedaży bezpośredniej, jak również kryteria warunkujące uznanie danej działalności za możliwą do realizacji jako sprzedaż bezpośrednia. Omówiono zasady opodatkowania działalności określanej jako sprzedaż bezpośrednia występujące w polskim prawie podatkowym. Przedstawiono zakres obowiązków spoczywających na rolnikach, a będących skutkiem prowadzenia działalności w ramach sprzedaży bezpośredniej.

Wprowadzone rozwiązania prawne dają możliwość zniwelowania dysproporcji szans oraz możliwości w zakresie produkcji i przetwarzania żywności między polskimi rolnikami a rolnikami z innych państw członkowskich UE.

\section{Literatura}

Projekt ustawy o zmianie niektórych ustaw w celu ułatwienia sprzedaży żywności przez rolników, http://legislacja.rcl.gov.pl/projekt/12284402 [dostęp: 18.12.2016].

Rozporzqdzenie Ministra Rolnictwa i Rozwoju Wsi z dnia 21 marca 2016 r. w sprawie szczegółowych warunków uznania działalności marginalnej, lokalnej i ograniczonej, Dz.U. 2016 r., poz. 451.

Rozporzadzenia Ministra Rolnictwa i Rozwoju Wsi z dnia 30 września 2015 r. w sprawie wymagań weterynaryjnych przy produkcji produktów pochodzenia zwierzęcego przeznaczonych do sprzedaży bezpośredniej, Dz.U. 2015 r., poz. 1703. 
Rozporzqdzenie Ministra Zdrowia z dnia 6 czerwca 2007 r. w sprawie dostaw bezpośrednich środków spożywczych, Dz.U. 2007 nr 112, poz. 774.

Rozporzqdzanie Parlamentu Europejskiego i Rady (UE) nr 1151/2012 z dnia 21 listopada 2012 r. w sprawie systemów jakości produktów rolnych i środków spożywczych, Dz.U. L 343 z 14.12.2012.

Rozporzadzenie(WE) nr 178/2002 Parlamentu Europejskiego i Rady z dnia 28 stycznia 2002 r., ustanawiajace zasady $i$ wymagania prawa żywnościowego, powołujace Europejski Urzqd ds. Bezpieczeństwa Żywności oraz ustanawiajace procedury w zakresie bezpieczeństwa żywności, Dz.U. L 031, 01/02/2002 P. 0001-0024.

Ustawa z dnia 26 lipca 1991 r. o podatku dochodowym od osób fizycznych, Dz.U. 2012 r., poz. $361 \mathrm{z}$ późn. zm.

Ustawa z dnia 9 kwietnia 2015 r. o zmianie ustawy o podatku dochodowym od osób fizycznych oraz niektórych innych ustaw, Dz.U. 2015 r., poz. 699.

Ustawa z dnia 16 listopada 2016 r. o zmianie niektórych ustaw w celu ulatwienia sprzedaży żywności przez rolników, Dz.U. 2016 r., poz. 1961.

Ustawa z dnia 16 grudnia 2005 r. o produktach pochodzenia zwierzęcego, Dz.U. 2014 r., poz. 1577 , z późn. zm.

Ustawy z dnia 16 listopada 2016 r. o zmianie niektórych ustaw w celu ułatwienia sprzedaży żywności przez rolników, Dz.U. 2016 r., poz. 1961.

Wytyczne dobrej praktyki higienicznej i produkcyjnej, gis.gov.pl/.../bz/wytyczne_ghp_podukcja_domowa_własne_uprawy.pdf [dostęp: 18.12.2016].

\title{
Carrying out and taxation principles of direct sales of processed agricultural products in Poland
}

\begin{abstract}
This paper presents decisions in force regarding legal acts regulating the direct sales by farmers in Poland. The current definition of direct sale, the conditions for its implementation and the principles of formation of the tax obligation are presented. Additionally, it presents the most important issues related to the carrying out direct sales of agricultural products by farmers. The principles of direct sales by farmers, the events which lead to the creation of the tax obligation connected with this sale and tax rules were discussed
\end{abstract}

Key words: direct sales, agricultural production, tax obligation, income tax 